\title{
AN ANALYSIS OF THE IMPACTS OF FINANCIAL INCLUSION ON INCOME INEQUALITY IN THE FRAGILE FIVE COUNTRIES
}

\author{
KIRILGAN BEŞLİ ÜLKELERINNDE FINANSAL KAPSAYICILIĞIN GELİR \\ EŞİTSİLİĞINE ETKILLERI ÜZERİNE BİR ANALİZ
}

\author{
Emrah DOĞAN* \\ Cengizhan GÜLER ${ }^{* *}$ iD
}

\begin{abstract}
The equitable distribution of income is a very important problem in the economies of the past and present. In this sense, this study aims to investigate the relationship between financial inclusion and income inequality in the fragile five countries (Colombia, Mexico, South Africa, Turkey, Indonesia). For this purpose, a comprehensive index of financial inclusion was constructed for the Fragile Five Countries. A panel data set from 2005 to 2008 was used for the study. The econometric methods used are Principal Component Analysis (PCA), Parks-Kmenta Estimator and Dumitrescu and Hurlin Panel Granger Causality test. The results show that there is a negative relationship between financial inclusion and income inequality. There is a statistically significant "inverse-U" shaped relationship between GDP per capita and income inequality in the fragile five countries. However, there is a statistically significant and negative relationship between internet usage and income inequality. In this regard, the findings of this study imply that fair growth and financial inclusion together help to reduce income inequality.
\end{abstract}

Keywords: Financial Inclusion, Income Inequality, Panel Data Analysis

JEL Classification: O15, O16, G20

Öz

Gelirin adil dağılımı, geçmişten günümüze ekonomilerde oldukça önemli bir sorundur. Bu anlamda bu çalışmada kırılgan beşli ülkelerinde (Kolombiya, Meksika, Güney Afrika, Türkiye, Endonezya) finansal kapsayıcılık ile gelir eşitsizliği arasındaki ilişkinin araştırılması hedeflenmiştir. Çalışmada 2005-2018 yılları arasındaki verileri içeren panel veri seti kullanılmıştır. Ekonometrik yöntem olarak Temel Bileşenler Analizi (PCA) yöntemi, Parks-Kmenta Tahmincisi ve Dumitrescu ve Hurlin tarafından geliştirilen Panel Granger Nedenselik testi kullanılmıştır. Elde edilen bulgulara göre, finansal kapsayıcılık ve gelir eşitsizliği arasında negatif bir ilişki olduğu gözlemlenmiştir. Kırılgan beşli ülkelerinde kişi başına GSYH ile gelir

* Asst. Prof. Dr., Istanbul Gelisim University, Faculty of Economics, Administrative and Social Sciences, International Trade and Finance Department, E-Mail: emdogan@gelisim.edu.tr, ORCID: 0000-0001-9870-5719

** Res. Asst., Istanbul Gelisim University, Faculty of Economics, Administrative and Social Sciences, International Trade and Finance Department, E-Mail: ceguler@gelisim.edu.tr, ORCID: 0000-0002-9059-3676 
eşitsizliği arasında istatistiki olarak anlamlı ve "Ters-U” biçimli bir ilişki vardır. Diğer taraftan internet kullanımı ile gelir eşitsizliği arasında ise istatistiksel olarak anlamlı ve negatif bir ilişki vardır. Bu bağlamda, bu çalışmanın bulguları, adil büyüme ve finansal kapsayıcılığın birlikte gelir eşitsizliğini azaltmaya yardımcı olduğunu ima etmektedir.

Anahtar Kelimeler: Finansal Kapsayıcılık, Gelir Eşitsizliği, Panel Veri Analizi

JEL Sinıflandırması: O15, O16, G20

\section{Introduction}

In recent years, the problem of income inequality has become more important in almost all modern economies, regardless of the country. For this reason, policy makers in modern economies are eager to develop policies aimed at a more equal and equitable distribution of income. However, when the policies designed and implemented in the historical process are evaluated, it is found that the policies developed are inadequate One of the main reasons for this situation is that the policies developed as a result of the prevailing economic structures in the time in which we live seem to be against lowincome groups, while retaining the benefits of high-income groups. This leads to a high degree of distorted and thus worsening income distribution.

In debates about income inequality, one of the most widely accepted views of how modern economies overcome the problem of income inequality is continuous economic development. However, as Park and Marcado $^{1}$ noted, the worsening of income equality, despite continued economic expansion, makes the problem even more difficult to solve. Therefore, rapid economic growth is successful when the socio-economic benefits are realized in the low-income groups. When considered in this context; It is an important element to ensure economic growth by creating widespread access to the products and services of financial institutions and channelling savings into productive areas across the board in economic geography. Evaluated in this light, the widespread use of products and services of financial institutions will accelerate economic growth. Income distribution will improve as the rapid increase in economic growth spreads to all strata of society. Therefore, improving the access of lowincome groups to financial services is one of the effective tools that help reduce income inequality ${ }^{2}$. At this point, financial inclusion, which can be expressed by making access to financial services more widespread and easier, especially for people from the low-income group, becomes crucial.

As mentioned earlier, financial inclusion is the process of bringing all individuals in the economy into the financial system and creating the opportunity to benefit from all the system's opportunities ${ }^{3}$. However, today more than $70 \%$ of the total world population still lacks access to some basic banking services. It is, therefore, necessary to ensure the integration of people belonging to low-income groups into the financial system and to deepen the financial system ${ }^{4}$. First, the products and services

1 Park, C. Y., Mercado, R., Jr. (2018). Financial Inclusion, Poverty, and Income Inequality, The Singapore Economic Review, 63(01): 185-206.

2 World Bank (2018). Toward Universal Financial Inclusion in China: Models, Challenges, and Global Lessons, World Bank Group, Washington, DC, p. 25-75.

3 Sarma, M. (2008). Index of Financial Inclusion (No. 215). Working Paper: p. 1-26.

4 Sehrawat, M., Giri, A. (2016). Panel Data Analysis of Financial Development, Economic Growth and Rural-Urban Income Inequality, International Journal of Social Economics, 43(10): 998-1015. 
of financial institutions will become more widely available, and people with low incomes will be able to use their savings to shape their future. Second, they will be able to find suitable financing for entrepreneurial activities. In this sense, financial inclusion is predicted to reduce income inequality in society. However, according to Le et al. ${ }^{5}$ the distortion of income distribution between low-income and high-income groups does not decrease when some countries become wealthier. This raises the question of whether financial inclusion, which is the subject of this study, helps to reduce income inequality by increasing access to financial resources.

The core of the theoretical approach to financial inclusion and income inequality is the inclusion of low-income households in the financial system. In other words, the prevention of disadvantage by the environments that regulate the financial system according to their own desires forms the basis of the theoretical approach. Accordingly, increasing financial inclusion enables low-income individuals to increase their income by rejoining the financial system ${ }^{6}$. Low-income households can access financial resources and benefit from employment opportunities created by new investments. Therefore, financial inclusion can be considered as one of the dynamic tools to achieve macroeconomic stability, sustainable and inclusive economic growth, job creation, poverty reduction and equitable income distribution ${ }^{7}$.

Another view argues that financial inclusion would reduce income inequality by promoting socioeconomic advantages through expanding access to financial services. From this perspective, disadvantaged groups that are mostly excluded from the financial system, such as low-income households, rural residents, and women, should be given the opportunity to benefit from basic financial services, such as deposit and saving accounts, borrowing, payments, and insurance. ${ }^{8}$. When this possibility is given, the potential savings of this group, excluded due to insufficient income levels and market discrimination, are included in the financial system and the level of investment resources is increased and the loss of wealth accumulation is reduced. Consequently, financial inclusion provides households and firms with greater access to resources to borrow to finance their consumption and investment, thereby increasing the level of economic activity. As a result, income inequality would be attenuated by increasing welfare in the economy in general, especially among groups excluded from the financial system ${ }^{9}$. At this point, it should be stressed that, as noted by Demirgüç-Kunt et. al ${ }^{10}$, the desire for financial inclusion to reach the whole of society does not mean giving credit to everyone. For the granting of credit to individuals without any conditions will lead to an inefficient use of savings. On the other hand, allowing anyone who wishes to do so to open a bank account at a low cost that they can reach and afford will not lead to such a negative situation.

5 Le, Q., Ho, H., Mai, N. (2019). The Impact of Financial Inclusion on Income Inequality in Transition Economies, Management Science Letters, 9(5): 661-672.

6 Omar, M. A., Inaba, K. (2020). Does Financial Inclusion Reduce Poverty and Income Inequality in Developing Countries? A Panel Data Analysis, Journal of Economic Structures, 9:1-25.

7 Omar, Inaba, 2020, 1-25.

8 World Bank (2014). Global Financial Development Report 2014: Financial Inclusion. World Bank Group, Washington, DC. https://openknowledge.worldbank.org/handle/10986/16238 (Accessed on: 14 June 2021)

9 Omar, Inaba, 2020, 1-25.

10 Demirgüç-Kunt, A., Klapper, L. F., Singer, D., Van Oudheusden, P. (2015). The Global Findex Database 2014: Measuring Financial Inclusion Around The World. World Bank Policy Research Working Paper, (7255): 1-97. 
The purpose of this study is to determine whether financial inclusion, an important topic of discussion in the literature, has an impact on income inequality. It is well known that structural problems such as high current account deficit, high inflation rates and unstable growth rates play an important role in income inequality. The fact that the countries designated as the Fragile Five face intense structural problems makes the issue even more important. In the assessment in this context, these countries were selected as the sample for the study based on the importance of the problem of income inequality in the fragile five countries. To this end, following the report published in 2016 by Morgan Stanley, the relationship between financial inclusion and income inequality in Colombia, Mexico, South Africa, Turkey and Indonesia, the fragile five countries, was investigated. This study has been prepare based on panel dataset, which contains data between 2005 and 2018, and the method Principal Components Analysis (PCA), the Parks-Kmenta Estimator and Dumitrescu and Hurlin Panel Granger Causality test. Given the intense debates about the impact of financial inclusion on income inequality, this study will make an empirical contribution to these debates. The most important feature that distinguishes the study from the other studies is that it provides a comprehensive index of financial inclusion for fragile five countries. If evaluated in this framework, the study is likely to make an important contribution to the literature.

In the study, the literature is first included, in which the results of the previous studies on the topic of the study are presented. Then, after presenting the data set and the method used in the study, the empirical findings obtained in the study are presented. Finally, the findings obtained in the study are evaluated and recommendations are made.

\section{Literature Review}

Before researching the effect of financial inclusion on income inequality in the literature, the relationship between financial inclusion and economic growth has been a widely studied research subject. According to Honahan ${ }^{11}$, it was accepted in the established literature that financial sector development had a negative effect on economic growth and subsequent income distribution and poverty. This view has changed with empirical studies accompanied by new data releases. Various studies, such as Li et. al ${ }^{12}$, Dehejia and Gatti ${ }^{13}$, Honohan ${ }^{14}$ have shown that financial development intensive growth reduces poverty. There are many studies in the literature that confirm this relationship. Following the studies that examined poverty and income inequality in the context of financial development, the index of financial inclusion (IFI), formed with different parametric variables, has been the subject of various studies in the economics literature, either alone or together with other phenomena. In short, financial inclusion aims to increase the welfare of individuals who are outside the financial system (mostly low-income groups) by giving them wider access to the

11 Honohan, P. (2004). Financial Development, Growth and Poverty: How Close Are The Links?. In Financial Development and Economic Growth (pp. 1-37). Palgrave Macmillan, London.

12 Li, H., Squire, L., Zou, H. F. (1998). Explaining International and Intertemporal Variations in Income Inequality. The Economic Journal, 108(446): 26-43.

13 Dehejia, R. H., Gatti, R. (2002). Child Labor: The Role of Income Variability and Access to Credit in a Cross-Section of Countries. Working Paper, p. 1-30.

14 Honohan, 2004, 1-37. 
products and services of financial institutions ${ }^{15}$. When we consider the context of widespread access, Demirguc-Kut et al. ${ }^{16}$ found that high financial inclusion was related to factors such as low banking costs, proximity to bank branches, and the need for less paperwork to open a bank account.

Various indices have been constructed in the literature by using different variables in relation to each context to measure financial inclusion. The index created by Sarma ${ }^{17}$ is widely used. In this index, financial inclusion is discussed in three dimensions. Namely, the share of the population with bank deposit accounts in the total population (penetration), bank branches per 1000 people (accessibility), and the ratio of each country's loan and deposit volume to GDP (usage). Another index summarises financial inclusion under four headings. The first focuses on the study of formal accounts, the second on the assessment of savings behaviour, the third on the source of borrowing, and the fourth on insurance benefits for health and agriculture ${ }^{18}$.

Looking at the relationship between financial inclusion, income inequality and poverty, we find that the corresponding topic has been analyzed in the economic literature with different methods and aspects. The main concern in this web of relationships is whether income inequality and poverty in society have decreased with increased economic activity as a result of financial inclusion. Therefore, it is very likely that poverty and income inequality will be reduced if income growth is in favor of low-income groups ${ }^{19}$. Studies on this topic consist of a combined analysis of financial inclusion and income inequality, financial inclusion and poverty, or both poverty and income inequality.

Considering the empirical studies that examined financial inclusion, income inequality, and poverty, Bae, Han and Sohn ${ }^{20}$ used the fixed effects panel regression model for the United States based on 2000-2007 and examined the effect of access to financial resources on income inequality and poverty. The financial inclusion variable created by the researchers was created considering several factors, just like the financial inclusion index. These factors are the number of financial institutions per 10.000 people, the number of financial institutions in an area of $100 \mathrm{~m}^{2}$ and the ratio of average deposit account to GDP per capita. The study found that access to financial resources reduces income inequality and poverty. Dhrifi ${ }^{21}$ examined the relationship between financial development, economic growth, income inequality and poverty in 89 countries between 1990 and 2011 using simultaneous equations. The results of the study concluded that financial development reduces poverty and income inequality in middle and high income countries. The results of the study concluded that financial development reduces poverty and income inequality in middle and high income countries but increases them in low-income countries.

15 Sarma, M. (2008). Index of Financial Inclusion (No. 215). Working paper: p. 1-26.

16 Demirguc-Kunt, A., Klapper, L., Peria, M. S. M. (2012). The Foundations of Financial Inclusion: Understanding Ownership and Use of Formal Accounts. The World Bank Working paper: p. 1-61.

17 Sarma, 2008, 1-26.

18 Demirguc-Kunt, Klapper, Peria, 2012, 1-61.

19 Jalilian, H., Kirkpatrick, C. (2002). Financial Development and Poverty Reduction in Developing Countries. International Journal of Finance \& Economics, 7(2): 97-108.

20 Bae, K., Han, D., Sohn, H. (2012). Importance of Access to Finance in Reducing Income Inequality and Poverty Level. International Review of Public Administration, 17(1): 55-77.

21 Dhrifi, A. (2015). Financial Development and the Growth-Inequality-Poverty Triangle. Journal of the Knowledge Economy, 6(4): 1163-1176. 
In another study, Seven and Coskun ${ }^{22}$ used panel regression analysis to analyze income inequality and poverty for the economies of 37 developing countries based on the performance of the banking sector and the stock market. According to the results of the study, it was found that banking sector development reduces inequality and poverty more effectively than the stock market.

In the study by Park and Mercado ${ }^{23}$, which examined financial inclusion, income inequality and poverty using panel regression analysis for 176 countries, including 37 developing Asian countries, a negative correlation was found between financial inclusion, income inequality and poverty, except for the developing Asian countries. For Asian developing countries, financial inclusion was found to have a positive effect on poverty reduction and no statistically significant causality was found with respect to income inequality. According to the authors, the possible reason for the lack of any causality for income inequality is that when financial inclusion increases, the increase captures every income group; thus, the effect is eliminated when measured by the Gini coefficient. According to the financial inclusion index formed by the researchers, it was observed that per capita income, rule of law, primary school completion and literacy are positively correlated with high financial inclusion.

As a result of the study conducted by Neaime and Gaysset ${ }^{24}$ using the generalized moments method for MENA countries between 2002 and 2015, it was found that financial inclusion reduced income inequality but had no effect on poverty. Moreover, for MENA countries, the authors pointed out that financial stability, financial inclusion and innovation can work simultaneously. In this context, it was observed that countries such as Tunisia and Morocco, unlike some MENA countries, use financial innovation and financial inclusion as supportive policies to reduce income inequality and poverty.

The relationship between income inequality and financial inclusion was analyzed in the study by Lan and Thuong ${ }^{25}$ using a two-stage least squares analysis for 22 transition countries between 2005 and 2015 and two different indices of financial inclusion. The result shows that there is a negative correlation between financial inclusion and income inequality.

The impact of financial inclusion on income inequality and poverty through information and communication technologies was investigated by Mushtaq and Bruneau ${ }^{26}$, using pooled least squares, fixed effects and random effects panel data analysis methods for 62 countries between 2001-2012. The results of the study showed that poverty decreased in parallel with the spread of microfinance. This result does not change when the Gini coefficient is used instead of the poverty variable.

22 Seven, U., Coskun, Y. (2016). Does Financial Development Reduce Income Inequality and Poverty? Evidence From Emerging Countries. Emerging Markets Review, 26: 34-63.

23 Park, Mercado, 2018, 185-206.

24 Neaime, S., Gaysset, I. (2018). Financial Inclusion and Stability in MENA: Evidence From Poverty and Inequality, Finance Research Letters, 24: 230-237.

25 Lan, H. H., Thuong, P. T. H. (2019). Financial Inclusion and Income Inequality: Empirical Evidence From Transition. Economies, Journal of Economics and Development, 21: 23-34.

26 Mushtaq, R., Bruneau, C. (2019). Microfinance, Financial Inclusion and ICT: Implications for Poverty And Inequality. Technology in Society, 59(101154): 1-19. 
Another study by Ouechtati ${ }^{27}$ analyzed the relationship between financial inclusion, income inequality and poverty using various methods dynamic panel data analysis between 2004 and 2017 for 53 developing countries. As a result of the study, it was found that financial inclusion is effective in reducing income inequality and poverty. It was observed that the number of bank branches per 100,000 people and the number of commercial banks per 1,000 people influence income inequality more than other financial inclusion variables at $1 \%$ and $5 \%$ significance levels. When the study is evaluated on the poverty axis, it was concluded that the variables of commercial banks per 1,000 people and number of commercial banks per 1,000 people are more effective in the financial inclusion index at $1 \%$ and $5 \%$ significance levels.

In a recent study, Omar and Inaba ${ }^{28}$ identified per capita income and internet usage in the positive sense and rate of dependent population, income inequality and inflation in the negative sense as determinants of financial inclusion using dynamic panel regression for 116 developing countries and fixed effects estimation method. According to the findings of the study covering 2004-2016 period, financial inclusion was found to be effective in reducing poverty and income inequality.

In another study, Bettin et al. ${ }^{29}$ analyzed on a single-country basis the relationship between financial inclusion and poverty using the dynamic random effects probit model for Italy over the period 2002-2016. The results suggest that financial inclusion has a positive effect on poverty reduction. Moreover, women and young people were found to be weaker than men and older people in terms of poverty-reducing financial inclusion. In this context, it was noted that protective measures should be taken for these people.

\section{Model, Dataset and Method}

\subsection{Dataset}

The study empirically examines the effect of financial inclusion in fragile five countries on income inequality. In this regard, the data used in the study were obtained from the IMF database and the World Bank database for the period 2005-2018. The study used the financial inclusion index (FI) to represent financial inclusion while examining the relationship between financial inclusion and income inequality in the fragile five countries. In examining the literature on this index, different financial inclusion indices and related indicators were used by the targets of different studies. Unlike other studies in the literature, this study creates a new financial inclusion index by using most of the indicators accessible from the financial inclusion indicators in the literature. The indicators covered in the study are shown in Table 1.

27 Ouechtati, I. (2020). The Contribution of Financial Inclusion in Reducing Poverty and Income Inequality in Developing Countries. Asian Economic and Financial Review, 10(9): 1051-1061.

28 Omar, Inaba, 2020, 1-25.

29 Bettin, G., Pigini, C., Zazzaro, A. (2020). Financial Inclusion and Poverty Transitions: An Empirical Analysis for Italy (No. 164), Money and Finance Research Group (Mo. Fi. R.) Working Paper, Univ. Politecnica Marche-Dept. Economic and Social Sciences. 
Table 1: Indicators Used to Form a Financial Inclusion Index

\begin{tabular}{|l|l|}
\hline Indicators & Source \\
\hline Number of ATM per 100 Thousand People & IMF - FAS Database \\
\hline Number of Non-Deposit Branches per $1000 \mathbf{k m}^{2}$ & IMF - FAS Database \\
\hline Branches Per 100 Thousand People & IMF - FAS Database \\
\hline Number of Deposit Accounts in Banks & IMF - FAS Database \\
\hline Credits / GDP (\%) & World Bank-WDI \\
\hline Number of ATMs per $1000 \mathbf{k m}^{2}$ & IMF - FAS Database \\
\hline Number of Branches per $1000 \mathbf{~ k m}^{2}$ & IMF - FAS Database \\
\hline Number of Deposits Per Thousand People & IMF - FAS Database \\
\hline Number of Insurance Companies Per 100 Thousand People & IMF - FAS Database \\
\hline
\end{tabular}

Source: IMF - FAS Database

In order to obtain the relative importance of the financial inclusion indicators and to construct a financial inclusion index for fragile five countries, the method Principal Components Analysis (PCA) was applied in the framework of the selected financial inclusion indicators. This method allows to develop a number of $\mathrm{k}$ unrelated variables by creating the relative weight of $\mathrm{p}$ number of indicators that are interconnected. In this method, the first step is to create a new dataset by reducing the dimensions. In the second step, unrelated principal component scores are calculated using related indicators ${ }^{30} 3132$. Finally, by listing each key component, the Financial Inclusion Index is calculated by considering the weights of the key component scores.

In addition to the financial inclusion index constructed in the study, real gross domestic product per capita (GDP), inflation rate (inf), trade openness (trade), and internet user rate (internet) were used (Table 2).

Table 2: Variables and Descriptions

\begin{tabular}{|l|l|l|l|}
\hline Variables & Descriptions of Variables & Source & Expected Signs \\
\hline GINI & $\begin{array}{l}\text { Income inequality is measured by the Gini } \\
\text { coefficient after deducting taxes and transfers. }\end{array}$ & $\begin{array}{l}\text { SWIID (version } \\
9.0)\end{array}$ & \\
\hline GDP & $\begin{array}{l}\text { Real gross domestic product per capita (USD at } \\
\text { constant 2010 prices). }\end{array}$ & $\begin{array}{l}\text { World Bank - } \\
\text { WDI }\end{array}$ & $-/+$ \\
\hline FI & Financial Inclusion Index & $\begin{array}{l}\text { Calculated By } \\
\text { Authors }\end{array}$ & - \\
\hline INF & Inflation Rate (\%) & $\begin{array}{l}\text { World Bank - } \\
\text { WDI }\end{array}$ & $-/+$ \\
\hline TRADE & $\begin{array}{l}\text { Trade Openness Ratio (\% of Foreign Trade in } \\
\text { GDP) }\end{array}$ & $\begin{array}{l}\text { World Bank - } \\
\text { WDI }\end{array}$ & $-/+$ \\
\hline INTERNET & $\begin{array}{l}\% \text { of people using the internet in the total } \\
\text { population }\end{array}$ & $\begin{array}{l}\text { World Bank - } \\
\text { WDI }\end{array}$ & - \\
\hline
\end{tabular}

Source: Authors, SWIID, World Bank

30 Johnson, R. A., Wichern, D. W. (2002). Applied Multivariate Statistical Analysis. Upper Saddle River, NJ, Prentice Hall, p. $430-480$.

31 Tatlıdil, H. (2002). Uygulamalı Çok Değişkenli İstatistiksel Analiz, Ankara, Cem Web Ofset Ltd, p. 601-612.

32 Özdamar, K. (2010). Paket Programlar ile İstatistiksel Veri Analizi-2 (Çok Değişkenli Analizler), Eskişehir, Kaan Kitabevi, p. 213-230. 


\subsection{Method}

The relationship between financial inclusion and income inequality in the fragile five countries was analysed using the Parks ${ }^{33}-\mathrm{Kmenta}^{34}$ Estimator and Dumitrescu and Hurlin ${ }^{35}$ panel Granger causality test. Among these methods, Parks-Kmenta Estimator provides effective estimates in the case of heteroskedasticity, autocorrelation, and the presence of cross-sectional dependence. Parks 36 developed an algorithm to predict a linear regression model in the case of correlation in addition to the presence of heteroscedasticity in the error terms of the model discussed. Kmenta ${ }^{37}$ pioneered the widespread use of this model by pointing out some of its existing shortcomings. The model developed by Parks-Kmenta makes it possible to obtain resistant standard errors without touching the parameter estimates. In this way, effective and consistent estimates can be made even when there is at least heteroskedasticity, autocorrelation and the presence of cross-sectional dependence in the model being predicted. Only in such a case can the model being predicted have an appropriate regression structure. Accordingly, the model structure generated by Parks-Kmenta,

$$
\mathrm{y}_{\mathrm{i}, \mathrm{t}}=\alpha_{\mathrm{i}}+\sum_{\mathrm{k}=2}^{\mathrm{k}} \alpha \mathrm{kx}_{\mathrm{kit}}+\mathrm{u}_{\mathrm{it}}
$$

Since the constant term and slope parameters in Equation 1 are fixed for all units and require fewer restrictions compared to least squares (OLS), it is constructed using generalized least squares (GLS). The GLS method provides estimates under the assumption that the variance-covariance matrix $(\Omega$ for the error terms is known. However, since this matrix is not known in the estimates, the flexible generalized least squares method is preferred. When evaluating in this context, it is necessary to obtain consistent predicted values of the variance-covariance matrix $(\Omega)$ in order to obtain the a-coefficients in $\mathrm{Eq} \bar{\Omega}{ }^{38}$.

On the other hand, in the Parks-Kmenta estimator, for the model to have an appropriate regression structure, $\mathrm{N}$ is expressed as the cross-sectional dimension in the panel data; If it is smaller than the time dimension $\mathrm{T}$, the model can have an appropriate regression structure. Because the Parks Kmenta - estimator is not flexible when $\mathrm{N}>\mathrm{T}$. In other words, when $\mathrm{T}>\mathrm{N}$, its predictor gives more effective and consistent results ${ }^{39}$. In this study, the Parks-Kmenta - estimator was preferred to obtain more accurate results because $\mathrm{T}>\mathrm{N}$ is valid.

The study analysed the causality relationship between financial inclusion and income inequality using Dumitrescu and Hurlin's panel Granger causality test. This method also gives effective and accurate results when the time dimension is larger than the cross-sectional size $(\mathrm{N}<\mathrm{T})$ or the cross-sectional

33 Parks, R. (1967). Efficient Estimation of a System of Regression Equations When Disturbances Are Both Serially and Contemporaneously Correlated, Journal of the American Statistical Association, 62: 500-509.

34 Kmenta, J. (1986). Elements of Econometrics (Second ed.), New York, Macmillan, p. 302-320.

35 Dumitrescu, E. I., ve Hurlin, C. (2012). Testing for Granger Non-Causality in Heterogeneous Panels, Economic Modelling, 29(4):1450-1460.

36 Parks, 1967, 500-509.

37 Kmenta, J. (1986). Elements of Econometrics (Second ed.), New York, Macmillan, p. 302-320.

38 Kmenta, 1986, 37.

39 Yerdelen Tatoğlu, F. (2013). Panel Veri Ekonometrisi (2. Baskı). İstanbul, Beta Yayınevi, p. 277. 
size is larger than the time dimension. ( $\mathrm{N}>\mathrm{T}$ In addition, the panel data to be used in this method must be balanced panel data or unbalanced panel data.

Dumitrescu and Hurlin, advantage of the panel Granger causality test is that it allows consistent estimates between variables when the units used in the panel have heterogeneous rather than homogeneous properties ${ }^{40}$. In this context, for the prediction of the causality relationship, the model Panel Vector Autoregression (PVAR) should be estimated first. Dumitrescu and Hurlin , obtained via the relevant panel VAR, can formulate the causality relationship as follows:

$$
\begin{aligned}
& \mathrm{y}_{\mathrm{i}, \mathrm{t}}=\alpha_{\mathrm{i}}+\sum_{\mathrm{k}=1}^{\mathrm{K}} \gamma i^{k} \mathrm{y}_{\mathrm{i}, \mathrm{t}-\mathrm{k}}+\sum_{\mathrm{k}=1}^{\mathrm{K}} \beta i^{k} \mathrm{x}_{\mathrm{i}, \mathrm{t}-\mathrm{k}}+\varepsilon_{\mathrm{i}, \mathrm{t}} \\
& \mathrm{y}_{\mathrm{i}, \mathrm{t}}=\alpha_{\mathrm{i}}+\sum_{\mathrm{k}=1}^{\mathrm{L}} v i^{l} \mathrm{x}_{\mathrm{i}, \mathrm{t}-\mathrm{l}}+\sum_{\mathrm{l}=1}^{\mathrm{L}} \sigma i^{l} \mathrm{x}_{\mathrm{i}, \mathrm{t}-\mathrm{l}}+\mathrm{u}_{\mathrm{i}, \mathrm{t}}
\end{aligned}
$$

The $\mathrm{x}$ and $\mathrm{y}$ in equations 2 and 3 above represent two stationary variables observed in period $\mathrm{T}$ for $\mathrm{N}$ number of cross-sectional data. Accordingly, $\gamma_{i}^{\mathrm{k}}$ represents the autoregressive parameter and $\beta_{\mathrm{i}}^{\mathrm{k}}$ represents the slope coefficients in equation no. 1 , which is used to determine whether there is causality from $\mathrm{x}$ to $\mathrm{y}$. While here the parameters are different for each cross section, the lag length expressed in $\mathrm{K}$ is the same for the entire cross section in the model being estimated. In this case for proving causality from $\mathrm{x}$ to $\mathrm{y}$;

H0: There is no causality relationship from $\mathrm{x}$ to $\mathrm{y}$ in all horizontal sections.

H1: There is a causality relationship from $\mathrm{x}$ to $\mathrm{y}$ in at least one horizontal section.

Hypotheses are set, as done above ${ }^{41}$.

To test the validity of the above hypotheses, 3 different test statistics are used. Accordingly, the first test statistic is the value of the forest statistic calculated using equation number 4 , which is the average of the forest statistics calculated on a unit basis. The second test is the $(\mathrm{N}<\mathrm{T})$ test statistic, which is used when the time measure obtained using Equation 5 is greater than the cross-sectional size. Finally, when the cross-sectional dimension is larger than the time dimension in the panel data analyzed $(\mathrm{N}>\mathrm{T})$, the third test statistic in Equation 6 is used.

$$
\begin{aligned}
& \mathrm{W}_{\mathrm{N}, \mathrm{T}}{ }_{\mathrm{HNC}}=\mathrm{N}^{-1} \sum_{\mathrm{i}=1}^{\mathrm{N}} W_{i, T} \\
& \mathrm{Z}_{\mathrm{N}, \mathrm{T}} \mathrm{HNC}^{\mathrm{H}}=\sqrt{\frac{N}{2 K}\left(W_{N, T}^{H N C}-K\right)} \\
& \mathrm{Z}_{\mathrm{N}}{ }_{\mathrm{HNC}}=\frac{\sqrt{N\left[W_{N, T}^{H N C}-N^{-1} \sum_{i=1}^{N} E\left(W_{i, T}\right)\right]}}{\sqrt{N^{-1} \sum_{i=1}^{N} \operatorname{Var}\left(W_{i, T}\right)}}
\end{aligned}
$$

40 Yerdelen Tatoğlu, F. (2017). Panel Zaman Serileri Analizi Stata Uygulamalı. İstanbul, Beta Yayıncllı: p. 151-154.

41 Ağazede, S., Karakaya, A. (2019). Finansal Gelişme ve Ekonomik Büyüme: OECD Ülkeleri Örneğinde Panel Nedensellik Analizi. Mehmet Akif Ersoy Üniversitesi İktisadi ve İdari Bilimler Fakültesi Dergisi, 6(2):471-484. 


\section{Empirical Findings}

\subsection{Principal Components Analysis Results}

Before presenting the empirical findings obtained in the study on the impact of financial inclusion on income inequality, it is necessary to identify the financial inclusion index (FI) considering the factors affecting financial inclusion in Table 1. In this context, financial inclusion is possible using the index principal component analysis. However, before applying the Principal Components Analysis method, it is necessary to decide whether the selected indicators of financial inclusion are suitable for Principal Component Analysis. For this purpose, Kaiser-Meyer-Olkin (KMO) and Bartlett tests are used. Field ${ }^{42}$ stated that the lower limit for the Kaiser-Meyer-Olkin test should be 0.50 . Thus, if the KMO test value in question is less than 0.50 , it can be said that the selected indicators are not suitable for principal component analysis. Accordingly, if the KMO value is greater than 0.50 and the Barlett test performed is significant, the principal component analysis method is suitable. Barlett Test and Kaiser-Meyer-Olkin test results obtained accordingly are given in Table 3.

Table 3: Kaiser-Meyer-Olkin ve Bartlett Test Results

\begin{tabular}{|l|l|l|}
\hline $\begin{array}{l}\text { Kaiser-Mayer-Olkin (KMO) } \\
\text { Sample Measurement Value Adequacy Test }\end{array}$ & \multicolumn{2}{|l|}{0.566} \\
\hline \multirow{2}{*}{ Barlett Test } & Chi-square & 168.30 \\
\cline { 2 - 3 } & Prob. & 0.00 \\
\hline
\end{tabular}

According to the test results given in Table 3, the KMO test score was found to be 0.56 . This result shows that the sample in this study is suitable for factor analysis. Moreover, the result of Barlett's test is statistically significant. These results indicate that the selected indicators of financial inclusion index are interrelated. Therefore, constructing the financial inclusion index using Principal Components Analysis is an appropriate method. The results of the analysis obtained by Basic Component Analysis accordingly are shown in Table 4.

Table 4: Unconverted Variance Values

\begin{tabular}{|l|l|l|l|}
\hline Factor & Eigenvalue & Variance Percent & Total Variance Percent \\
\hline Factor $\mathbf{1}$ & 4.574955 & 0.5083 & 0.5083 \\
\hline Factor $\mathbf{2}$ & 2.319874 & 0.2578 & 0.7661 \\
\hline Factor 3 & 1.404959 & 0.1561 & 0.9222 \\
\hline
\end{tabular}

Since there are three components with an eigenvalue greater than one in the results of Principal Components Analysis given in Table 4, the analysis was performed considering these values. Accordingly, it can be seen that the first component explains $50.8 \%$ of the total variance, the second component explains $25.7 \%$ and the third component explains $15.6 \%$. Moreover, these three components account for $92 \%$ of the total variance in the construction of the financial inclusion

42 Field, A. (2000). Discovering Statistics Using SPSS for Windows. London, Thousand Oaks, New Delhi, Sage Publications, p. 456-467. 
index. Table 5 reports the rotated factor loadings corresponding to the selected indicators of financial inclusion. In the factor analysis conducted to uncover the factor design, the factor loading value was found to be 0.30 .

Table 5: Components Matrix Table

\begin{tabular}{|c|c|c|c|}
\hline Indicators & Factor 1 & Factor 2 & Factor 3 \\
\hline Number of ATM per 100 Thousand People & 0.324852 & 0.326140 & -0.308586 \\
\hline Number of Non-Deposit Branches per 1000 km² $^{2}$ & 0.112941 & 0.299574 & 0.713299 \\
\hline Branches Per 100 Thousand People & 0.372364 & -0.203762 & -0.271581 \\
\hline Number of Deposit Accounts in Banks & 0.434159 & -0.021888 & 0.218597 \\
\hline Credit / GDP (\%) & 0.048572 & 0.629670 & -0.096313 \\
\hline Number of ATMs per $1000 \mathrm{~km}^{2}$ & 0.453202 & 0.085920 & 0.103833 \\
\hline Number of Branches per $1000 \mathrm{~km}^{2}$ & 0.412225 & -0.145924 & 0.306702 \\
\hline Number of Deposits Per Thousand People & 0.358583 & 0.163421 & -0.400382 \\
\hline $\begin{array}{l}\text { Number of Insurance Companies Per } 100 \text { Thousand } \\
\text { People }\end{array}$ & -0.219783 & 0.556797 & -0.003030 \\
\hline
\end{tabular}

According to the results in Table 5, the indicators with the highest factor loadings are in the 1st component: Number of ATMs per 100 thousand people, Number of branches per 100 thousand people, Number of branches per 100 thousand people, Number of Deposit Accounts in banks, Number of ATMs per $1000 \mathrm{~km}^{2}$, Number of branches per $1000 \mathrm{~km}^{2}$, Number of deposits per thousand people. These indicators explain the highest percentage of the total variance in the financial inclusion index. Therefore, these indicators are the most important indicators of financial inclusion in the fragile five countries. In contrast, the indicators with the highest factor loading in component 2 are: number of ATMs per 100,000 population, credit / GDP (\%), number of insurance companies per 100,000 population. Thus, these indicators are secondary indicators of financial inclusion in the fragile five countries. Finally, the indicators with the highest factor loading in the third component are the number of Non-Deposit Branches per $1000 \mathrm{~km}^{2}$ and the number of branches per $1000 \mathrm{~km}^{2}$. These values imply that they are complementary indicators of financial inclusion in the fragile five countries. Using these values, the study constructed the financial inclusion index and the following part of the study analyzed the relationship between the financial inclusion index and income inequality obtained from Principal Components Analysis.

\subsection{Model Estimation Results}

This part of the study estimates equation 7 and provides evidence on the effect of financial inclusion on income inequality.
GINIit $=\alpha i+\beta 1$ LOGGDPit $+\beta 1$ LOGGDP2it $\beta 3$ FIit $+\beta 4$ INFit + $\beta 5$ TRADEit + $\beta 6$ INTERNETit + sit

The basic hypothesis for the model to be estimated using equation \#7 can be expressed as follows:

H1: The level of financial inclusion has a direct impact on income inequality. 
H2: Financial Inclusion and Income Interaction provide the validity of the Kuznets Curve

According to these hypotheses, financial inclusion allows low-income households to access financial services. This will enable low-income households to accumulate more assets for future use, and hence earn higher income in the future. This will result in a direct impact on income inequality. Therefore, it is possible to test the $\mathrm{H}_{2}$ hypothesis as well as the $\mathrm{H}_{1}$ basic hypothesis with the help of the model established in the study. In addition, descriptive test statistics for the variables used to test these hypotheses are given in Table 6.

Table 6: Descriptive Test Statistics for Variables

\begin{tabular}{|l|l|l|l|l|}
\hline Variables & Mean & Standard Error & Minimum & Maximum \\
\hline GINI & 0.486 & 0.077 & 0.40 & 0.635 \\
\hline GDP & 7874 & 3131 & 2524 & 15190 \\
\hline FI & $-6.09 \mathrm{e}-09$ & 2.154 & -3.267 & 5.117 \\
\hline INF & 5.116 & 2.582 & -4.704 & 13.108 \\
\hline TRADE & 52.43 & 11.32 & 34.26 & 80.44 \\
\hline INTERNET & 43.40 & 28.89 & 3.602 & 97.301 \\
\hline
\end{tabular}

In order to determine the relationship between financial inclusion and income inequality in the fragile five countries, it is first necessary to establish the existence of an inter-unit correlation for the countries that make up the panel data, i.e., cross-sectional dependence. In this framework, a cross-sectional dependence test was first conducted prior to the analysis of the study. That is, we tested whether a shock that occurs in the series affects all cross-sections to the same extent ${ }^{43}$. As noted by Breusch and Pagan ${ }^{44}$ and Pesaran ${ }^{45}$, the presence of cross-sectional dependence between variables in panel data analysis significantly affects the analysis results, to prevent the results from being inconsistent and deviating from equilibrium, the presence of cross-sectional dependence in series should be detected. In this framework, the LM cross-sectional dependence test developed by Breusch and Pagan ${ }^{46}$ was performed because $T$, which represents the number of observations in the period, is larger than the number $\mathrm{N}$, which represents the sum of cross-sections in the panel data. The corresponding results obtained from the cross-sectional dependence test are shown in Table 7.

Table 7: Test Results of Cross Section Dependence

\begin{tabular}{|l|l|}
\hline Test & Statistic Value \\
\hline LM Test & 10.998 \\
\hline P Value for LM Test & 0.35 \\
\hline
\end{tabular}

43 Akçay, A. Ö., Erataş, F. (2012). Cari Açık ve Ekonomik Büyüme İlişkisinin Panel Nedensellik Analizi Ekseninde değerlendirilmesi. Türkiye Ekonomi Kurumu, UEK-TEK 2012 İzmir, p. 22.

44 Breusch, T. S., Pagan, A. R. (1980). The Lagrange Multiplier Test and Its Applications to Model Specification in Econometrics", Review of Economic Studies, Blackwell Publishing, 47 (1): 239-253.

45 Pesaran, M. H. (2004). General Diagnostic Tests for Cross-sectional Dependence in Panels. Empirical Economics, 1-38.

46 Breusch, Pagan, 1980, 239-253. 
According to the LM test results in Table 7, the null hypothesis stating that there is no cross-sectional dependence in the fragile five countries is accepted. This result can be evaluated as there is no crosssectional dependence among the units that constitute the panel. In the study, after cross-sectional dependence, the stationary properties of the variables were examined. Since the cross-sectional dependence was not detected in the panel data used in the study, the stationarities of the variables from the first-generation unit root tests, the unit root test of Levin, Lin and Chu ${ }^{47}$ (LLC) unit root test and Maddala and $\mathrm{Wu}^{48}$ tests. It is given in Table 8.

Table 8: Results of Levin, Lin and Chu Unit Root Test and Maddala and Wu Unit Root Test

\begin{tabular}{|l|l|l|}
\hline Variable Name & Levin, Lin ve Chu Test Statistic & Maddala ve Wu Test Statisctic \\
\hline GINI & $-2.16^{* *}$ & $16.204^{*}$ \\
\hline LOGGDP & $-2.79^{* * *}$ & $22.371^{* *}$ \\
\hline FI & $-2.81^{* * *}$ & $50.362^{* *}$ \\
\hline INF & $-4.87^{* * *}$ & $29.691^{* *}$ \\
\hline TRADE & $-2.45^{* * *}$ & $20.651^{* *}$ \\
\hline INTERNET & $-5.73^{* * *}$ & $74.329^{* * *}$ \\
\hline
\end{tabular}

Note: The deterministic specification of the tests includes fixed and trend. In addition, ${ }^{*} 0.10,{ }^{* *} 0.05$ and ${ }^{* * *} 0.01$ indicate significance levels.

From the unit root test results in Table 8, it can be seen that the variables in the panel used in the study are stationary. In other words, according to the test results obtained, all the series considered were found to contain no unit root in their original state, that is, they are stationary at the $\mathrm{I}(0)$ level.

In the next step of the study, a modified Wald Test was conducted to determine if the variance problem was observed, which can lead to errors and discrepancies in model estimation results. To determine the autocorrelation problem in the model, Wooldridge autocorrelation test was performed, and the test results are presented in Table 9.

Table 9: Heteroskedasticity and Autocorrelation Test Results

\begin{tabular}{|l|l|}
\hline Test Name & Test Statistic \\
\hline Modified Wald Testi & $42307(0.00)$ \\
\hline Wooldridge autocorrelation test & $13.38(0.02)$ \\
\hline
\end{tabular}

Note: Values in the parentheses refer to the probability values of the variables.

As can be seen from the test results in Table 9, it can be said that there is both a heteroskedasticity and an autocorrelation problem in the model, since the probability value of both tests is less than 0.05. As previously emphasized, more effective estimation results are obtained using the Parks-Kmenta Estimator when at least one of the heteroskedasticity, autocorrelation, and

47 Levin, A., Lin, C. F., Chu, C. S. J. (2002). Unit Root Tests in Panel Data: Asymptotic and Finite-Sample Properties. Journal of Econometrics, 108(1):1-24.

48 Maddala, G. S., Wu, S. (1999). A Comparative Study of Unit Root Tests with Panel Data and A New Simple Test. Oxford Bulletin of Economics and statistics, 61(S1): 631-652. 
cross-sectional dependence are present in the models discussed and also T $>$ N. For this reason, the model was estimated with the help of Parks-Kmenta estimator due to the existence of heteroskedasticity and autocorrelation problem and $\mathrm{T}>\mathrm{N}$ status in the study. These results are given in Table 10 .

Table 10: Parks-Kmenta Model Prediction Results

\begin{tabular}{|l|l|}
\hline Variables & Coefficients \\
\hline LOGGDP & $2.548(5.94)^{* * *}$ \\
\hline LOGGDP $^{2}$ & $-0.144(-5.72)^{* * *}$ \\
\hline FI & $-0.002(-1.94)^{* *}$ \\
\hline INF & $0.0007(0.57)$ \\
\hline TRADE & $0.0001(0.32)$ \\
\hline INTERNET & $-0.001(-3.51)^{* * *}$ \\
\hline Number of Observation:70 & Prob:0.00 \\
\hline
\end{tabular}

Note: Values in parentheses are $\mathrm{z}$ statistics values. In addition, ${ }^{\star} 0.10,{ }^{* *} 0.05$ and ${ }^{* * *} 0.01$ indicate significance levels.

According to the results of Parks-Kmenta - estimation presented in Table 10, although there is a positive and statistically significant relationship between GDP per capita and income inequality in the fragile five countries. There is a statistically significant and negative relationship between GDP per capita squared and income inequality. In other words, there is an "inverse-U" shaped relationship between income and income inequality. This result is consistent with the hypothesis developed by Kuznets ${ }^{49}$ that the increase in income in the early stages of economic development increases income inequality, while income inequality decreases in the later stages.

There is a statistically significant and negative relationship between financial inclusion and income inequality, which is also the main research subject of the study. This result implies that increased financial inclusion is effective in reducing income inequality in the fragile five countries. In other words, financial inclusion implies that individuals from the low and irregular income group have higher access to financial services as a result of the financial reforms implemented by the countries. This implies that as these individuals are able to save for the future, the increase in their income contributes to the reduction of income inequality. Thus, it can be said that increased financial inclusion helps to distribute income more equitably in countries with highly skewed income distribution. This finding obtained in the study is in line with Omar and Inaba ${ }^{50}$, Dabla-Norris et al. ${ }^{51}$, GarciaHerrer and Turégano ${ }^{52}$ and Salazar-Cantú et al. ${ }^{53}$. On the other hand, these findings different from

49 Kuznets, S. (1955). Economic Growth and Income Inequality, The American Economic Review, 45(1): 24-37.

50 Omar, Inaba, 2020, 1-25.

51 Dabla-Norris E, Deng Y, Ivanova A, Karpowicz I, Unsal F, VanLeemput E, Wong J (2015). Financial Inclusion: Zooming in on Latin America. IMF Working Paper 15/206. Washington, DC. https ://www.imf.org/exter nal/pubs/ft/wp/2015/ wp152 06.pdf.

52 Garcia-Herrer A, Turégano DM (2015). Financial Inclusion, Rather Than Size, Is The Key to Tackling Income Inequality. BBVA Research Working Paper 15/05. Madrid, Spain. https ://www.bbvar esear ch.com/wp-conte nt/uploads/2015/02/ WP_Finan cial-Inclu sion-Incom e-Inequality 4.pdf.

53 Salazar-Cantú J, Jaramillo-Garza J, Rosa BÁ (2015). Financial Inclusion and Income Inequality in Mexican Municipalities. Open J Soc Sci, 3: 29-43. 
Honohan ${ }^{54}$, Park and Mercado ${ }^{55}$ studies. Honohan ${ }^{56}(2007,2008)$ and Park and Mercado ${ }^{57}$ stated that there is insufficient empirical evidence that financial inclusion reduces income inequality. It should be noted that these differences may be due to reasons such as the time period chosen in these studies and the methodology used to measure financial inclusion.

On the other hand, as with financial inclusion, it was found that there is a statistically significant and negative relationship between increases in internet usage and income inequality. In other words, higher internet usage in the fragile five countries means that it is effective in reducing income inequality. Given this result, the shift of traditional financial services to an electronic basis such as internet banking, i.e., the use of the internet, may increase financial inclusion through access to information. This means that individuals in these low-income groups can earn more income by assessing their future savings. This increases the future income of individuals in low-income groups and helps reduce income inequality.

As with Omar and Inaba ${ }^{58}$, other variables hypothesised to affect income inequality were found to be non-significantly related to the degree of openness and income inequality. Similarly, inflation rate from the control variables: Its coefficient is positive, as expected, but not statistically significant. The prediction results of the Parks-Kmenta model can be evaluated since the $\mathrm{H} 1$ and $\mathrm{H} 2$ hypotheses tested in the study are both accepted.

Finally, in order to verify the obtained results between financial inclusion and income inequality, the causality relationship between these two variables was analyzed using the Granger causality test of Dumitrescu and Hurlin Panel. Before starting this analysis, it is necessary to determine the homogeneity of the model created. This is because depending on the heterogeneity of the parameters in the model, the panel Granger causality test of Dumitrescu and Hurlin would be appropriate in the study. Since T> N is valid in the panel data discussed in this framework, Swammy ${ }^{59}$ heterogeneity test performed, and the results are given in Table 11. According to the results of the Swammy test for the analysis of heterogeneity, given in Table 11. It can be seen that the null hypothesis that the parameters of the models are homogeneous is rejected. From this finding, it is concluded that the parameters of the model are heterogeneous. In this context, Dumitrescu and Hurlin's panel Granger causality test, which accounts for heterogeneity, seems appropriate. This result also implies that the interaction between financial inclusion and income inequality differs across the fragile five countries.

Table 11: Heterogeneity Test Results

\begin{tabular}{|l|l|l|}
\hline Test & Test Statisctic & Probability Value \\
\hline $\mathrm{Chi}^{2}$ & 3104.05 & $0.000^{* * *}$ \\
\hline
\end{tabular}

Note: ${ }^{\star} 0,10,{ }^{* *} 0,05$ and ${ }^{* * *} 0,01$ indicate significance levels.

54 Honohan, P. (2008). Cross-Country Variation in Household Access to Financial Services. Journal of Banking \& Finance, 32(11): 2493-2500.

55 Park C, Mercado R. V. (2015). Financial Inclusion, Poverty, and Income Inequality in Developing Asia. ADB Economics Working Paper Series 426/2015. Manila, Philippines. https ://www.adb.org/sites /defau lt/files /publi catio n/153143/ ewp-426.pdf., (Accessed on 14.06.21)

56 Honohan, 2008, 2493-2500.

57 Park, Mercado, 2015.

58 Omar, Inaba, 2020, 1-25.

59 Swamy, P. (1970). Efficient Inference in a Random Coefficient Regression Model, Econometrica, 38(2): 311-323. 
In order to perform the panel Granger causality test of Dumitrescu and Hurlin it is first necessary to determine the appropriate number of lags for the variables. Accordingly, the values indicating the selection criteria for lag length are included in Table 12. According to the values of the lag length selection criteria in Table 12, the appropriate lag for the variables was determined to be 2. From this point of view, the results of the Granger causality test for the panel of Dumitrescu and Hurlin between financial inclusion and income inequality for fragile five countries were obtained, and these results are reported in Table 13.

Table 12: Determining Lag Length

\begin{tabular}{|l|l|l|l|l|}
\hline Lag Length & J & MBIC & MAIC & MQIC \\
\hline $\mathbf{1}$ & 13.05 & $-25.57^{\star}$ & -10.94 & -15.00 \\
\hline $\mathbf{2}$ & 2.51 & -23.23 & $-13.48^{*}$ & $-16.18^{\star}$ \\
\hline $\mathbf{3}$ & 0.85 & -12.01 & -7.14 & -8.49 \\
\hline
\end{tabular}

According to the empirical results, the null hypothesis $\mathrm{H}_{0}$, which states that there is no causal relationship from financial inclusion to income inequality, is rejected. Similarly, the null hypothesis $\mathrm{H}_{0}$ which states that there is no causal relationship between income inequality and financial inclusion was rejected. According to this result, it can be said that there is a two-way causal relationship between financial inclusion and income inequality. Therefore, the $\mathrm{H}_{1}$ hypothesis which states that the level of financial inclusion has a direct effect on income inequality was confirmed by the results of the Granger causality test of the panel of Dumitrescu and Hurlin.

Table 13: Dumitrescu and Hurlin (2012) Panel Granger Causality Test Results

\begin{tabular}{|l|l|l|}
\hline Causality Direction & Statistic Value & Probability \\
\hline $\mathrm{fi} \rightarrow$ gini & 3.85 & $0.00^{* * *}$ \\
\hline gini $\rightarrow \mathrm{fi}$ & 5.22 & $0.00^{* * *}$ \\
\hline
\end{tabular}

Note: ${ }^{\star} 0,10,{ }^{* *} 0,05$ and ${ }^{* *} 0,01$ indicate significance levels.

\section{Concluding Remarks}

Studies of the income inequality of countries have been a great curiosity in recent years. Although there is no universally accepted view on the causes and solutions of income inequality, the economic growth performance of countries is an important determinant of income inequality. Although rapid increases in economic growth performance have real effects on income inequality, they are not enough. Financial inclusion, which is the main topic of this study, has become an important element in solving the problem of income inequality. Financial inclusion contributes to faster growth and stability in economies, especially in developing countries. More importantly, financial inclusion ensures more equitable growth by providing access to financial services to individuals from low and irregular income groups. Financial inclusion thus gives income groups that do not have access to the financial system in countries the chance to access the financial system and thus increase their income. This reduces income inequality. When assessing in this context, it is of great importance to analyse the impact of financial inclusion on income inequality and take appropriate policy measures. 
This study aimed to investigate the relationship between financial inclusion and income inequality in the fragile five countries. This was analysed using the panel data set, which contains the data between 2005 and 2018, and the method Principal Components Analysis (PCA), the Parks-Kmenta Estimator and the Panel Granger Causality test developed by Dumitrescu and Hurlin. The empirical results show that the effect of financial inclusion on income inequality is negative and statistically significant. This result implies that financial inclusion enables low - and middle-income groups, which currently have a low share of financial services, to have a higher share of these products and services, increasing their ability to invest and earn returns, thereby increasing welfare levels. Therefore, increasing financial inclusion has the effect of fixing inequality in income distribution and reducing poverty. While there is a positive and statistically significant relationship between GDP per capita and income inequality in the fragile five countries, there is a statistically significant and negative relationship between GDP per capita squared and income inequality. This can be assessed as an "inverse- $U$ " shaped relationship between financial inclusion and income inequality. It was found that there is a negative and statistically significant relationship between internet usage and income inequality, which is another variable believed to influence on income inequality.

These results show that the interaction between financial inclusion, economic growth, and internet usage has a significant moderating effect on income inequality. However, the interaction between financial inclusion and economic growth performance in the fragile five countries implies that the increase in economic growth initially led to increased income inequality. The main reason for this can be seen in the small marginal effects of financial inclusion. However, the increase in financial inclusion and the subsequent increase in the level of economic development of the fragile five countries increase the marginal effects of financial inclusion. Consequently, economic growth reduces income inequality in the final stage. In other words, increased financial inclusion leads to more equal economic growth and thus reduces income inequality.

On the other hand, the results obtained using the panel Granger Causality test developed by Dumitrescu and Hurlin also show that there is a bidirectional causality relationship between financial inclusion and income inequality. Therefore, this result can be evaluated in the sense that the level of financial inclusion has a direct effect on income inequality.

In the context of the study's findings, it can be said that financial inclusion helps to reduce income inequality. This is done not only by increasing financial inclusion but also by increasing marginal efficiency due to the interaction with various factors such as fair growth and internet usage. For example, the labor demand created by strong and fair growth leads to higher wages for individuals in the low-income group. This improves living standards and welfare levels. With this improvement, increasing financial inclusion contributes to the development of an efficient and inclusive financial system by providing access to the financial system for poor individuals. At the end of this process, fair growth and financial inclusion together contribute to the reduction of income inequality. Therefore, in economies with highly skewed income distribution, such as the fragile five countries, it is possible to reduce income inequality if reforms are implemented that support the living standards and welfare of lower-income groups and increase the efficiency and inclusiveness of the financial system. 


\section{References}

AĞAZEDE, S., Karakaya, A. (2019). Finansal Gelişme ve Ekonomik Büyüme: OECD Ülkeleri Örneğinde Panel Nedensellik Analizi, Mehmet Akif Ersoy Üniversitesi İktisadi ve İdari Bilimler Fakültesi Dergisi, 6(2): 471-484.

AKÇAY, A. Ö., Erataş, F. (2012). Cari açık ve Ekonomik Büyüme İlişkisinin Panel Nedensellik Analizi Ekseninde değerlendirilmesi, Türkiye Ekonomi Kurumu, UEK-TEK 2012 İzmir: 1-24.

BAE, K., Han, D., Sohn, H. (2012). Importance of Access to Finance in Reducing Income Inequality and Poverty Level, International Review of Public Administration, 17(1): 55-77.

BETTIN, G., Pigini, C., Zazzaro, A. (2020). Financial Inclusion and Poverty Transitions: An Empirical Analysis for Italy (No. 164), Money and Finance Research Group (Mo. Fi. R.) Working Paper, Univ. Politecnica Marche-Dept. Economic and Social Sciences.

BREUSCH, T. S., Pagan, A. R. (1980). The Lagrange Multiplier Test and Its Applications to Model Specification in Econometrics, Review of Economic Studies, Blackwell Publishing, 47(1): 239-253.

DABLA-NORRIS E, Deng Y., Ivanova A., Karpowicz I., Unsal F., Vanleemput E., Wong J. (2015). Financial Inclusion: Zooming in on Latin America, IMF Working Paper 15/206. Washington, DC.

DEHEJIA, R. H., Gatti, R. (2002). Child Labor: The Role of Income Variability and Access to Credit in A CrossSection of Countries, Working paper: 1-30.

DHRIFI A. (2015). Financial Development and The Growth-Inequality-Poverty Triangle, Journal of the Knowledge Economy, 6(4): 1163-1176.

DEMIRGUC-KUNT, A., Klapper, L., Peria, M. S. M. (2012). The Foundations of Financial Inclusion: Understanding Ownership and Use of Formal Accounts, The World Bank.

DEMIRGUC-KUNT, A, Klapper, L. F., Singer, D., Van Oudheusden, P. (2015). The Global Findex Database 2014: Measuring Financial Inclusion Around the World, World Bank Policy Research Working Paper, (7255): 1-61.

DUMITRESCU, E. I., Hurlin, C. (2012). Testing for Granger Non-Causality in Heterogeneous Panels, Economic Modelling, 29(4): 1450-1460.

FIELD, A. (2000). Discovering Statistics Using SPSS for Windows, London, Thousand Oaks, New Delhi, Sage Publications.

GARCIA-HERRERG A., Turegano D. M. (2015). Financial Inclusion, rather than Size, is the Key to Tackling Income Inequality, BBVA Research Working Paper 15/05. Madrid, Spain.

HONOHAN, P. (2008). Cross-country Variation in Household Access to Financial Services, Journal of Banking \& Finance, 32(11): 2493-2500.

HONOHAN, P. (2004). Financial Development, Growth and Poverty: How Close Are the Links? in Financial Development and Economic Growth, London, Palgrave Macmillan.

JALILIAN, H., Kirkpatrick, C. (2002). Financial Development and Poverty Reduction in Developing Countries, International Journal of Finance \& Economics, 7(2): 97-108.

JOHNSON, R. A., Wichern, D. W. 2002. Applied Multivariate Statistical Analysis, Upper Saddle River, NJ, Prentice Hall.

KMENTA, J. (1986). Elements of Econometrics (Second ed.), New York, Macmillan: 302-320.

KUZNETS, S. (1955). Economic Growth and Income Inequality, The American Economic Review, 45(1): 24-37.

LAN, H. H., Thuong, P. T. H. (2019). Financial Inclusion and Income Inequality: Empirical Evidence from Transition, Economies, Journal of Economics and Development, 21: 23-34. 
LE, Q., Ho, H, Mai, N. (2019). The Impact of Financial Inclusion on Income Inequality in Transition Economies, Management Science Letters, 9(5): 661-672.

LEVIN, A., Lin, C. F., Chu, C. S. J. (2002). Unit Root Tests in Panel Data: Asymptotic and Finite-Sample Properties, Journal of Econometrics, 108(1): 1-24.

LI, H., Squire, L., Zou, H. F. (1998). Explaining International and Intertemporal Variations in Income Inequality, The Economic Journal, 108(446): 26-43.

MADDALA, G. S., Wu, S. (1999). A Comparative Study of Unit Root Tests with Panel Data and a New Simple Test, Oxford Bulletin of Economics and Statistics, 61(S1): 631-652.

MUSHTAQ, R., Bruneau, C. (2019). Microfinance, Financial Inclusion and ICT: Implications for Poverty and Inequality, Technology in Society, 59(101154): 1-19.

NEAIME, S., Gaysset, I. (2018). Financial Inclusion and Stability in MENA: Evidence from Poverty and Inequality, Finance Research Letters, 24: 230-237.

OMAR, M. A., Inaba, K. (2020). Does Financial Inclusion Reduce Poverty and Income Inequality in Developing Countries? A Panel Data Analysis, Journal of Economic Structures, 9: 1-25.

OUECHTATI, I. (2020). The Contribution of Financial Inclusion in Reducing Poverty and Income Inequality in Developing Countries, Asian Economic and Financial Review, 10(9): 1051-1061.

ÖZDAMAR, K. (2010). Paket Programlar ile İstatistiksel Veri Analizi-2 (Çok Değişkenli Analizler), Eskişehir, Kaan Kitabevi.

PARK, C., Mercado, R. V. (2018). Financial Inclusion, Poverty, and Income Inequality, The Singapore Economic Review, 63(01): 185-206.

PARK, C., Mercado R. V. (2015). Financial Inclusion, Poverty, and Income Inequality in Developing Asia. ADB Economics Working Paper Series 426/2015. Manila, Philippines, https://www.adb.org/sites/default/ files/publication/153143/ewp-426.pdf (Accesed on: 14 June 2021)

PARKS, R. (1967). Efficient Estimation of a System of Regression Equations When Disturbances Are Both Serially and Contemporaneously Correlated, Journal of the American Statistical Association, 62: 500-509.

PESARAN, M. H. (2004). General Diagnostic Tests for Cross-sectional Dependence in Panels, Empirical Economics: 1-38.

SALAZAR-CANTUS, J., Jaramillo-Garza, J., Rosa, B.Á. (2015). Financial Inclusion and Income Inequality in Mexican Municipalities, Open Journal of Social Sciences, 3: 29-43.

SARMA, M. (2008). Index of Financial Inclusion (No. 215), Working Paper: 1-26.

SEHRAWAT, M., Giri, A. (2016). Panel Data Analysis of Financial Development, Economic Growth and RuralUrban Income Inequality, International Journal of Social Economics, 43(10): 998-1015.

SEVEN, U., Coşkun, Y. (2016). Does Financial Development Reduce Income Inequality and Poverty? Evidence from Emerging Countries, Emerging Markets Review, 26: 34-63.

SWAMMY, P. (1970). Efficient Inference in a Random Coefficient Regression Model, Econometrica, 38(2): 311323.

TATLIDİL, H. 2002. Uygulamalı Çok Değişkenli İstatistiksel Analiz, Ankara, Cem Web Ofset Ltd.

WORLD BANK (2014). Global Financial Development Report 2014: Financial Inclusion. World Bank Group, Washington, DC. https://openknowledge.worldbank.org/handle/10986/16238 (Accessed on 14 June 2021).

WORLD BANK (2018). Toward Universal Financial Inclusion in China: Models, Challenges, and Global Lessons, World Bank Group, Washington, DC.

YERDELEN TATOĞLU, F. (2013). Panel Veri Ekonometrisi (2. Bask1), İstanbul, Beta Yayınevi.

YERDELEN TATOĞLU, F. (2017). Panel Zaman Serileri Analizi Stata Uygulamalı, İstanbul, Beta Yayıncılık. 